\title{
風土に基づいた都市色彩計画に関する研究 \\ 一東京都江東区を事例として一 \\ URBAN COLOR DESIGN BASED ON CULTURAL CLIMATE \\ Case study of Koto ward, Tokyo
}

\author{
尾 崎 真理*，金 敬 仁**，小林 正美*** \\ Mari OZAKI, Gyungin KIM and Masami KOBA YASHI
}

\begin{abstract}
When we examine the phenomena of climate created by the interaction between nature and human beings, we can find colors of cultural climate. The cultural climate colors are those obtained from colors of natural landscape such as soils, trees, flowers, water, skies etc. and those obtained from historical \& cultural heritages such as traditional buildings, textiles, art crafts and etc. of the land. The cultural climate colors could provide beautiful townscape harmonizing each other. This study aims to develop a method of urban color planning that can create color harmony in townscape. Koto ward of Tokyo metropolitan area is surveyed as the case study site. Outer wall colors of present buildings are measured and analyzed and cultural climate colors of Koto ward are collected. The proposed color planning method is to choose the hue from the trend of the color of present buildings and to choose the tone from cultural climate colors. In the designing process, the colors of soils and skies are used for the base colors of the buildings while the colors of flowers, art crafts and festivals are used for the accent colors.
\end{abstract}

Keywords : Cultural Climate, Natural Environment's Color, Historical \& Cultural Environmental's Color, Present Urban Colors, Color Planning 風土 自然環境の色 歴史・文化環境の色 都市現況色彩 色彩計画

\section{1.研究の背景及び目的}

「風土とは、ある土地の気候、気象、地質、地味、地形、景観な どの総称である。（中略）我々はさらに風土の現象を文芸、美術、 宗教、風習などあらゆる人間生活の表現の中に見いだすことができ る。」非自然環境とそこの人間との関わりによって形成された風土 の現象を観察すると、風土がつくってきた色が読み取れる。

自然環境が生み出す色彩は多様であり、地域によってそれぞれ特 徵ある構成を持ち、その差異が地域の歴史や文化を特徽あるものに 育ててきた。地域の色彩（風土色）は、その土地の自然環境をもと に、歴史・文化環境の蓄積と洗練化によって形成されるものであ る。長い年月をかけてその土地に相応しい色が風土の色として定着 し、人々に認識され引き継がれていく。即ち、風土色は、その土地 に調和する色であり、美しい風景をつくる色である。

伝統的民家は、その建てられている地域の気候・地形、歴史・生 活文化と密接な関わりを持って保持されており、地場産材料の活用 によって地域の自然色に相応しい環境色彩の形成が図られていた。 しかし、最近の建物にはかつて使われていなかった人工材料や塗料 が大量に供給され、さらに、それらが周辺との調和を考えることな しに、その土地以外のものをそのまま取り入れ、都市の色彩景観に
混乱をもたらしている場合も少なくない。その背景には、その土地 独特の自然や歴史・文化即ち、風土を無視した色使いがなされてき たからである。

地域の色彩は、「その地域の個性」を形成する重要な景観構成要 素であり、時代の表層的流行に左右されない色彩計画によることが 望ましい。それぞれの地域には異なった歴史があり、地理・気象・ 文化などの条件を踏まえ、地域の自然景観の色に相応しい独自性を 持った色彩計画をしなければならない。それぞれの都市の風土や地 区の特性に従い、現在の都市の色彩状况に対応した色彩の選択や色 彩誘導の方法を展開すべきである。

本研究は、江東区を事例として、既存建築物の外壁色と地域の風 土がつくってきた色を中心とした色彩特性を調べ、都市景観におけ る調和のある色彩をもたらすとともに地域の個性を育むことのでき る色彩計画の方法を示すことを目的とする。

\section{2. 研究の方法}

\section{(1) 調查対象地}

江東区は、東京湾に面し、その内陸部において、首都圈の主要工 業地帯の一翼を担い、住・商・工の「混合」地域として発展してき た。昭和40年以降には、工場の区内移転による跡地への集合住宅建

\footnotetext{
* 侏オズカラースタジオ 代表取締役

** 韓国標準科学研究院 博士 (土学)

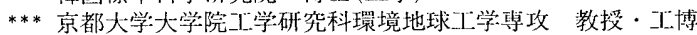

OZ Color Studio Inc.

Korea Research Institute of Standards and Science, Dr. Eng.

Prof., Dept. of Global Environment Eng., Graduate School of Eng., Kyoto Univ., Dr. Eng. 
設がすすみ、「住宅」都市としての性格を併せ持つようになった。 そして近年は、副都心、臨海副都心構想の影響もからみ、「業務」 機能が拡大・進出してきている。東京の臨海部に位置づけられ様々 な都市問題を抱えながら、東京とともに発展してきている都市であ る 古くからの歴史文化遺産が多く残されている所でもある。（図1）

調査は、「江東区都市景観ガイドライン注」に基づき、また歴史 的な経緯と地域特性の共通性から 5 つの地域に分け、調査結果の分 析及び色彩計画の提案を行った。各地域の概要を以下に示す。(図2) (1)深川北地域は、川沿いに大規模工場と會庫がならび、その内側に 住・商・工の混在地を形成し、歴史的・空間的に重要財産が多い。 (2)深川南地域は、中心業務と臨海工業地区としての機能を備之、小 規模団地やマンションが多く、近隣公園が少ない。

(3)亀戸・大島地域は、住宅系や専用商業施設が最も多く、社寺・旧 跡などの歴史的ストックがある。また、住・商・工が混在した職住 近接型の地域社会を形成している。

(4)砂町地域は、かつては工場主体のまちであったが、土地利用の変 換等から住宅主体のまちに変化している。

(5)臨海地域は、東京湾に面した大きなウォーターフロントであり、 新しい都市づくりをめざし臨海副都心開発計画が進められている。

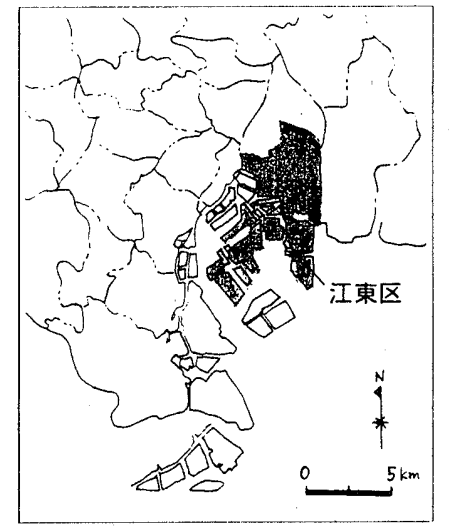

\section{図1 調查対象地}

(2) 研究の方法

色彩計画の提案を行うため、調查のフローを次ぎのように作成し た。（図3）

(1)調査対象地域の概要を把握する。

(2)既存建築物の外壁色を測色し、その色彩分布の傾向を分析する。

(3風土色を、自然環境に関わる色と歴史・文化環境に関わる色に分 けて調べ、その色彩群（パレット）を抽出する。

(4)以上の(2)項と(3)項の分析結果と、対象地域の特性を踏まえ、各地 域別の色彩特徽を出す。

(5)地域にふさわしい色彩計画への提案を行う。

\section{3. 既存建築物の現況色彩}

現況色彩の傾向を把握するため、既存建築物の外壁色を調べる。 （1）調查方法

本調査は、「江東区都市景観ガイドライン」の地域区分に従って 5 地域 10 地区に分けて行った。調査地点は、各地域ごとに建物の棟

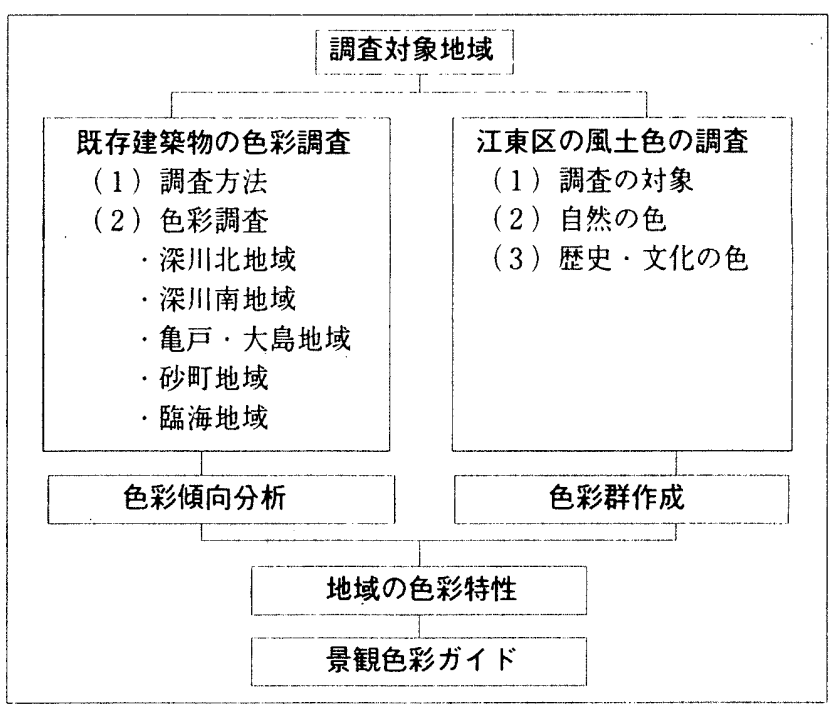

図3 調查フロー

数に応じて、全部で120力所を選定した（表1）。その調査地点から 色彩的に大きく視野を占める建築物（上位 5 棟）について外壁色を 調べた（1棟で一色以上が使われているときは、使われている色を 全部を測色した）。測色は視感測色を行い、測色した色をマンセル

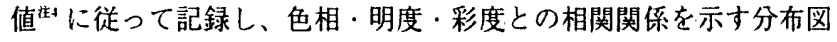
を作成した。分布図の点は、各色相における明度と彩度の值を示

し、值が同じである場合は重ねて表示した。従って頻度は表示され ないので調査棟数より分布点の数は少なくなる。測定時間は、自然 光が安定している午前10時から午後3時の間に行った。

表1 調查地点の選定

\begin{tabular}{|c|c|c|c|c|}
\hline & & & & \\
\hline 地域 & 地区 & 既存建築物の悚数 & 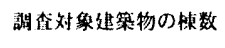 & 調梠地点数 \\
\hline \multirow{3}{*}{ 深川北 } & 画河 & 7,965 & 80 & 16 \\
\hline & 小松㛢 & 5,622 & 60 & 12 \\
\hline & 蒚阙 & 5,269 & 50 & 10 \\
\hline \multirow{2}{*}{ 深川南 } & 東陽 & 3,468 & 40 & 8 \\
\hline & 豊洲 & 2,732 & 25 & 5 \\
\hline \multirow{2}{*}{ 龟戸・大㿟 } & 龟労 & 9.202 & 90 & 18 \\
\hline & 大島 & $8.3 \mathrm{~A} 2$ & 80 & 16 \\
\hline \multirow{2}{*}{ 砂町 } & 砂町 & 10,322 & 100 & 20 \\
\hline & 南砂 & 5.900 & 60 & 12 \\
\hline 糮海 & 監海 & 1,518 & 15 & 3 \\
\hline 合計 & & 60,340 & 600 & 120 \\
\hline
\end{tabular}

（2）調査分析

建築物の外壁の色をマンセル値に従って記録し、各色の色相・明 度・彩度を基に色彩分布図を作成する。これは現況色彩の全体的傾 向と特徵を定量的に分析するものである。各地域別色彩分布傾向を 以下に示す。

(1)深川北地域（図4）

明度6.5 9、彩度1３の黄赤（YR）系と黄（Y）系が多く、中明 度の多様な彩度をもった赤（R）系も多い。他の地域に比べ青（B） 
系が多く、青系は、青緑（BG）系～青紫（PB）系まで幅広く、 色々なトーンが見られる。緑 $(\mathrm{G})$ 系や赤紫 $(\mathrm{RP})$ 系が最も多い。
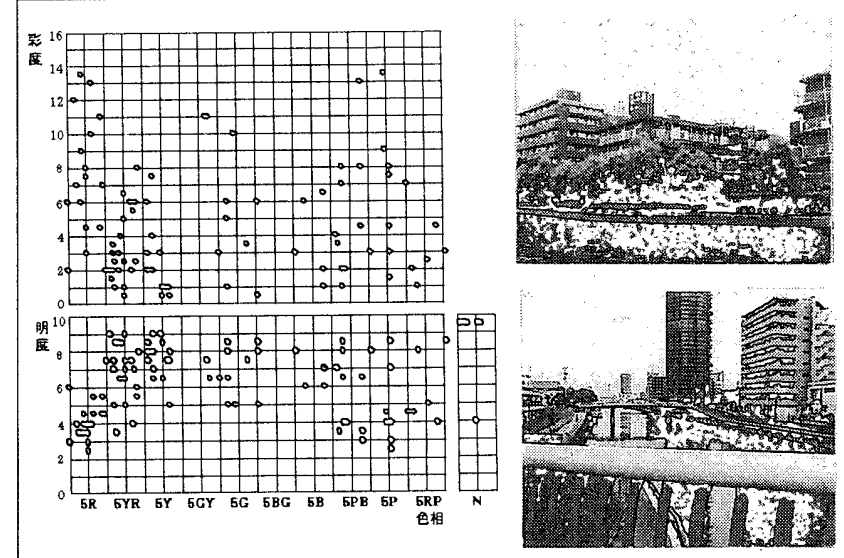

图4 深川北地域の現況分布

(2)深川南地域（図5)

明度6９、彩度1～30黄赤 (YR) 系と黄 $(Y)$ 系に集中的に分布 している。他の地域と比べ赤 $(\mathrm{R})$ 系が最も少なく、無彩色が最も 多い地域である。

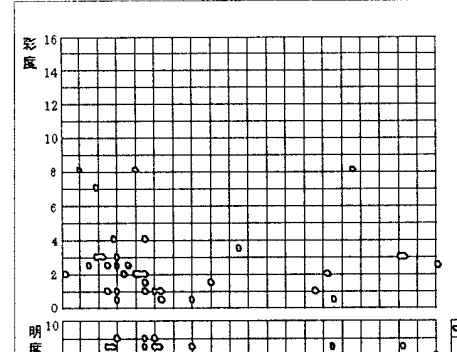

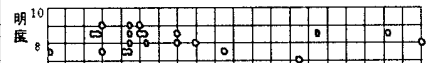
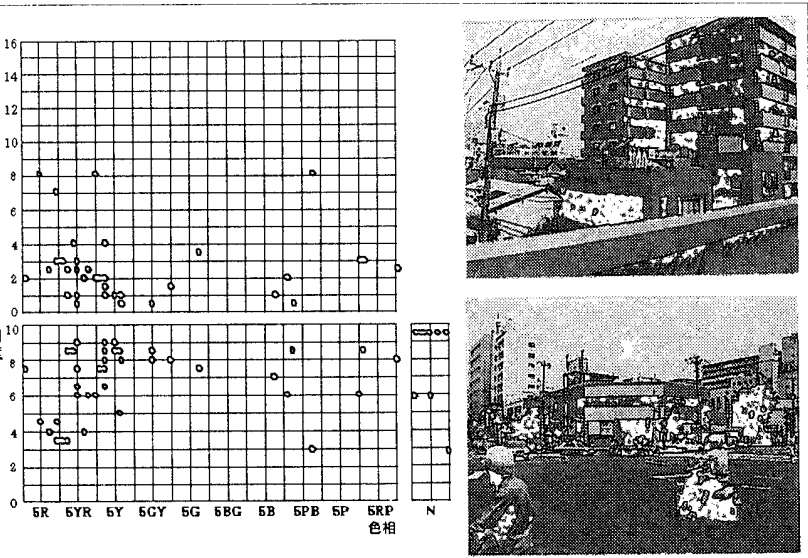

图5 深川南地域の現況分布

(3)亀戸・大島地域（図6）

明度5９、彩度1～5の黄赤（YR）系、黄 $(\mathrm{Y})$ 系に集中し、明る く低彩度色の变化が多い地域である。他の地域と比べ緑系が多く、 その影響で青系においても緑みのある青緑（BG）系が多い。
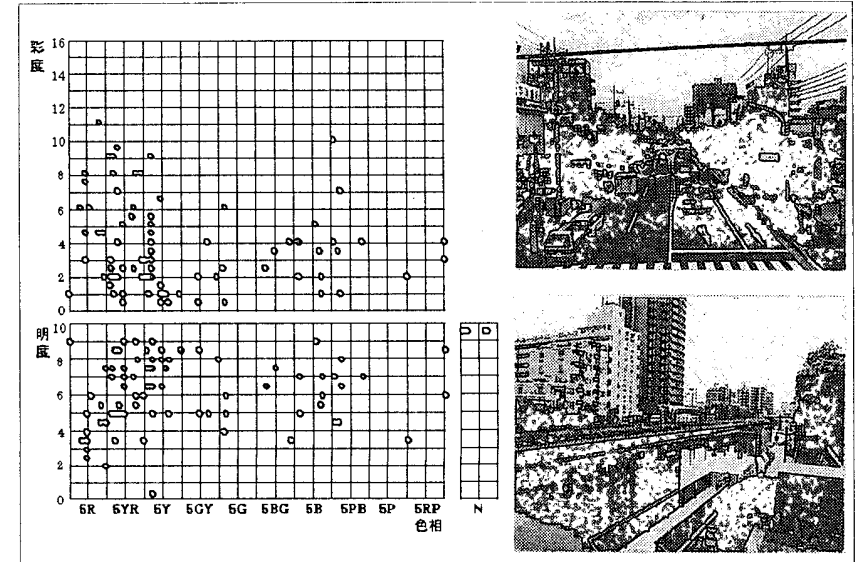

图6 龟玄・大島地域の現況分布

(4)砂町地域（図7)

明度6９、彩度1～3の黄赤（YR）系と黄 $(Y)$ 系に集中的に分布

し、紫みのある青紫 $(\mathrm{PB})$ 系が多い。この地域は黄(Y)系が多い。

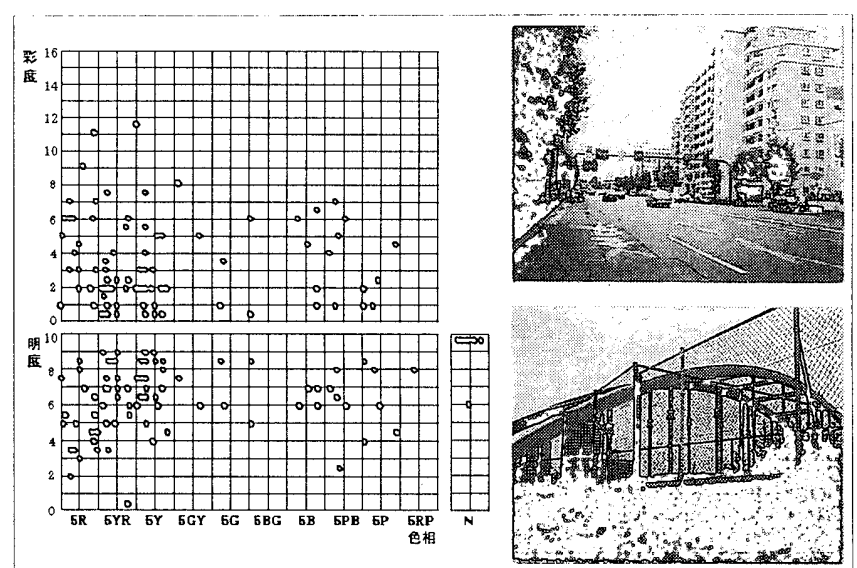

図7砂町地域の現況分布

(5)臨海地域（図8）

明度7 9、彩度 $0.5 \sim 20$ 黄 (Y) 系、青紫 $(\mathrm{PB})$ 系が多く、明る い色調を持った地域である。特に、緑（G）が最も少ない。

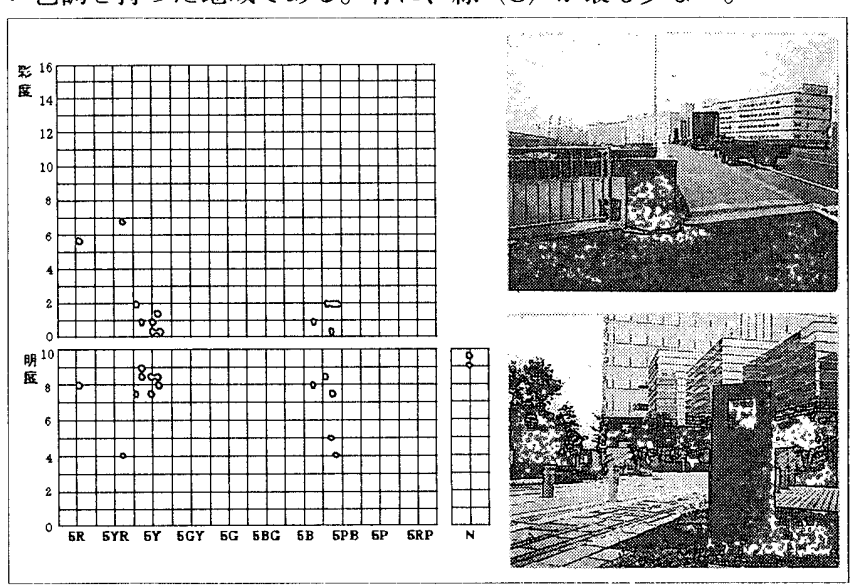

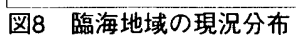

(3) まとめ

既存建築物によって現況色彩を分析すると、この中には、外壁色 としては不適合な色である高明度色や高彩度色、中明度・高彩度の 濃い色、白に近い無彩色が多く使われている。特に、青（B）系の 分布がばらついている。これらは、まとまりのない景観を形成し、 まちを乱れる重要な要因になっているといえよう。特に、現在べー スとして使われている色は、この地の風土が䏍んできている木、

花、空、土壌の色よりあざやかな（彩度が高い）色である。アクセ ントであるべき色をべースとして用いたため、不調和をきたしてい るといえよう。

\section{4. 江東の風土色}

江東区の色彩特性を調べるため、風土が生み出した色を調べた。 (1) 調㚗対象

風土色は、その土地のすべての人間の生活から見いだすことが可 能であるが、本研究では江東区史を中心に江東の特徴を現している 要素から色を抽出した。江東区の風土色は、「自然環境に関わる 色」と「歴史・文化環境に関わる色」という2つの視点を設け、次 ぎのような要素を調査の対象とした。(図9)

自然環境に関わる色は、その地域の気候、地形や地質等風土の基 本的な条件と直接関係するものを取り上げ、土壤、植物、花、空と 水の色を調べた。 
歴史・文化に関わる色は、その地域における人々の生活・文化の 積み重ねが形になったものとして捉え、歴史的建築物、浮世絵、祭 り、工芸品、の礼ん、地名の色を調べた。

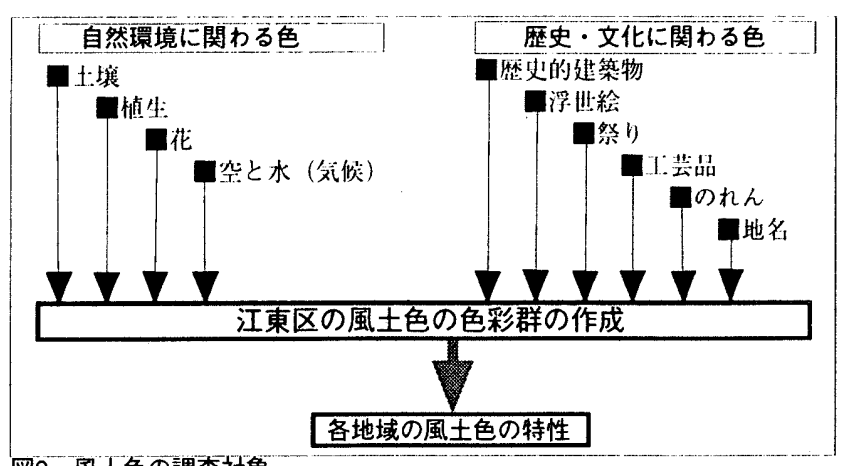

図9 風土色の調查対嗮

（2）江東区の風土色

以上の調查対象に基づき、江東区の風土によって育まれてきた色 を収集した。(図10、図11)

1)自然環境の色

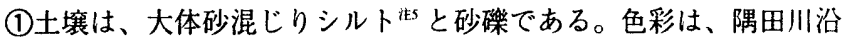
いの深川北地域や亀戸地域では明度差が大きく色みが強いのに対 し、荒川沿いの砂町地域では黄みのある明るい色が中心であった。

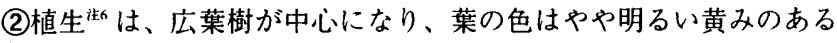
緑色である。樹種構成は、大きく内陸地域と沿岸地域に分けて考之 ると、内陸地域にはクスノキ、ケヤキ、イチョウ、サクラが多く、 沿岸地域にはユーカリ、アカシア、ヤナギが数多く存在する。 (3)花は、江東区の四季を代表し、この地域に馴染んでいる代表的な ものは江東区の花であるサザンカ（暗赤紫）、亀戸天神のフジ（薄 青紫）、牡丹町のボタン（軳やかな赤紫）、亀戸天神のウメ（紅 梅）、荒川河川のナノ八ナ(やや緑みのある黄色）、仙台堀川のサ クラ（うすいピンク色）などがある。

(4)空の色 ${ }^{\text {i7 }}$ は、色相は7.5B $3.5 \mathrm{~PB}$ 、明度は2.5 5.5 (浮世絵) 、8.5 (実際)、彩度は3.0－5.0（浮世絵）、1.0 (実際) で紫がかった青 い色合いである。水の色は、色相は5GY〜5G（川）、7.5BG〜7.5B

（海）、明度は3.5（川）、4.0〜7.0（海）、彩度は2.0（川）、2.0～ 4.0 (海) で川の色は黄みがかった濃い緑色を、海の色はやや緑みの ある青色を呈している。

2)歴史・文化環境の色

(1)歴史的建築物は、深川北地域では低彩度 ·中明度の黄赤系を基調 と寸る明るい赤茶系が多く、深川南地域では明るい赤茶系と緑色が 多い。また、亀戸・大島地域では濃い茶色が中心になり色みのない 無彩度色に近い色が特徴であるが、砂町地域では砂壁の黄赤系を中 心とした明るい色と赤みのある濃い茶系が見られる。

(2)深川の庶民の姿・農村の風景・まちなみの風景・木場などの様子 を描いた浮世絵洂を通してみると、深川北地域のものは赤、緑、江 戸紫、藍色などの多様な色相が見られ、他の地域より紫やくすんだ 色が多い。深川南地域のものは明るい黄色系が多く赤棟瓦の色が特 徵である。また、亀戸・大島地域のものは服飾の藍色や周辺の緑の 暗緑色が特徵であり赤みのある黄色系が中心になっている。砂町地
域のものは菜の花色、砂色が中心である。

(3祭り（ハレの日）では神舆やハッピの色を調べた。富岡八幡祭り では 7 つの色（紫色・水色・橙色・茶色・赤色・緑色・紺色）の神 輿によって7つの地域を見分けている。また、媣川力持ち、木場の 角乗、木場の木遣、手古舞などの伝統芸能は、江東区の産業や文化 に関連している。そのハッピの色には、木の色や深川鼠が主に使わ れている。

(4)工芸品には、江戸こま（赤、黒、金）、江戸切子（赤と青）、提 灯 (白·黒·黄·赤·青)、江戸更紗 (白・赤紫・橙色)、組みひ も（白・赤紫・淡緑・薄緑・橙）などがある。

(5のれんの色には、浅葱色、はなだ色、紺・藍色、茶色、柿茶色、 白地などがある。

(6)地名からの色は、常盤町からの常盤色、現亀戸地区に柳島という 地名から柳葉色、深川から深川鼠などがある。

（3）まとめ

風土色の色使いからは色彩構成原理も読み取れる。即ち、空、土 といった自然環境の中で大きな面積を占める色は風固の中ではべー スカラーになる。一方、祭りの時のハッピ、旗の色は日常生活の中 でのハレの日の色であり、アクセントカラーである。花の色は緑の 中、自然環境の中のアクセントである。工芸品の色も日常生活環境 の中でのアクセントになっている。

\section{5. 色彩計画への提案}

まず、色彩計画の基本的な考え方を示し、地域別提案色を示す。

(1) 色彩計画の考え方

(1)色の選定について

各地域の提案色は既存建築物の色彩分布傾向で多く見られる色相 を選び、それに当てはまる色調（トーン：明度+彩度）の色を風土色 から選ぶ。

都市機能が多様に変化しつつある今日のまちなみ固観に対応さ せ、地域の色相特性を活か寸ため、既存建築の壁面色の色相傾向を 提案色に採用する。また、日照や湿度など異なる自然環境条件に よって培われてきた風土色からその色相に当てはまる色調を選ぶ。 (2)色使いについて

建築物の外観の色彩構成は、大きな面積に使われるべースカラー注 とサブベースカラー注10、線として使われるフレームカラー涂"、点と して使われるアクセントカラージに分け、提案を行う。

先にも述べたように、風土色の色使いからは色彩構成原理が読み 取れる。即ち、自然の風景の中で土や空の色は日常的な色であり大 きな面積を占め、常に変わらぬ同じ色としてある都市や建物のべー スカラーとして使える。一方、花、工芸品、祭りの色などは八レの 色であり生活の中でアクセントとなり、建物の一部など小さい面積 に使えるものである。高層建築物は高さを増すになるにつれて空に 溶达むように薄い高明度色を使う。

\section{（2）地域別提案色}

以上の色彩計画の考え方に従い、5つの地域の提案色を図120よ うに示す。3.（2）の調査分析を基に集中的な色彩分布傾向を示して 


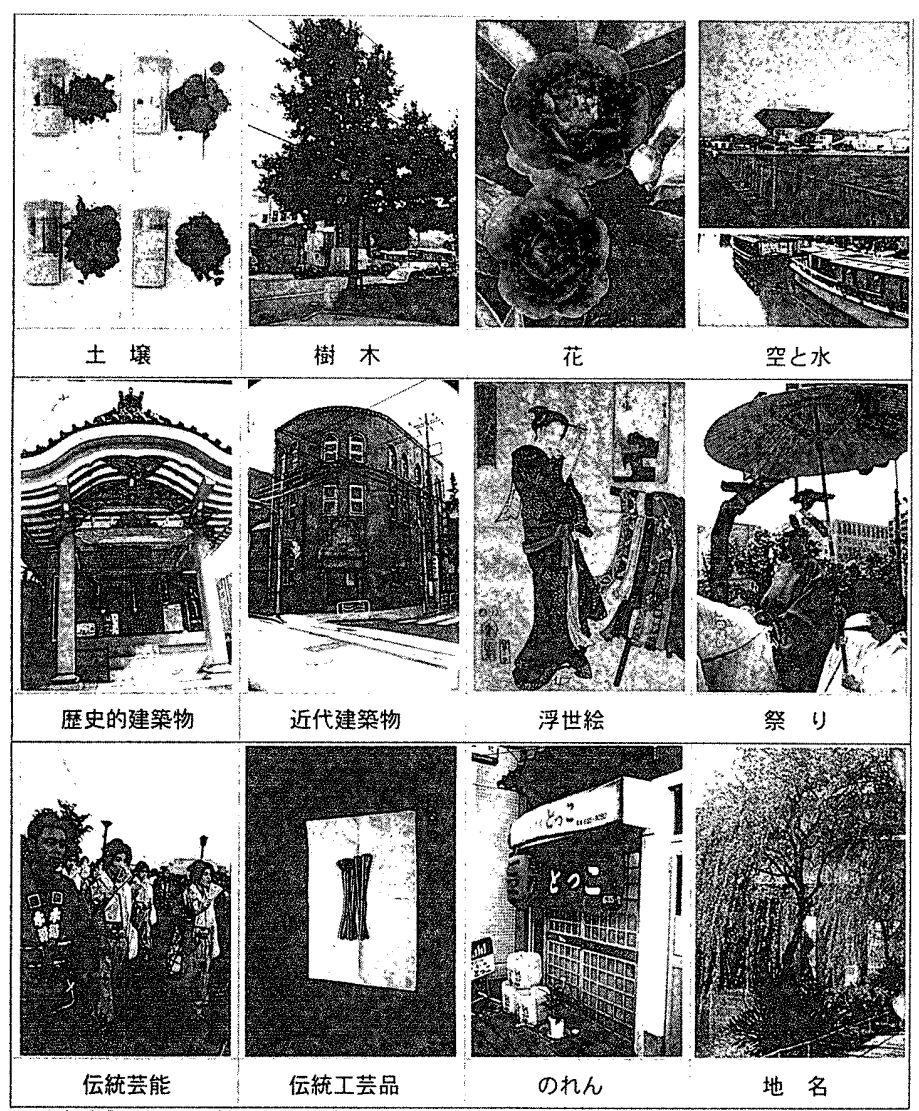

图10江菓区の風土色採取例

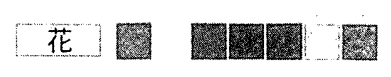

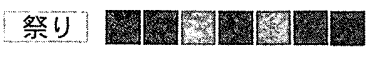

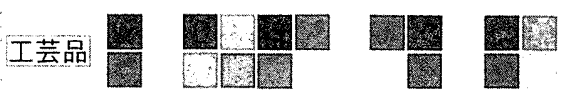

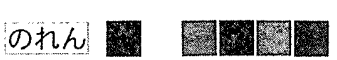

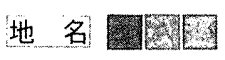

絵 㘣
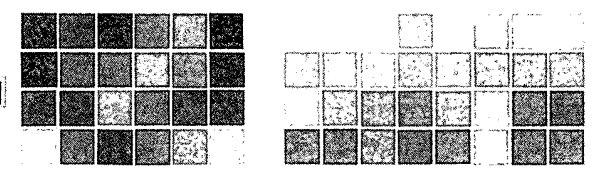

四

犘央的物 園国 空と水:

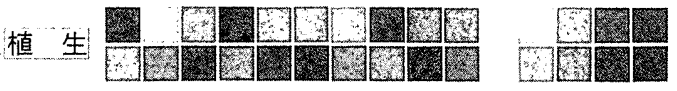
W]

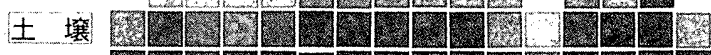

図11江東区の風土色の色彩群（パレット）

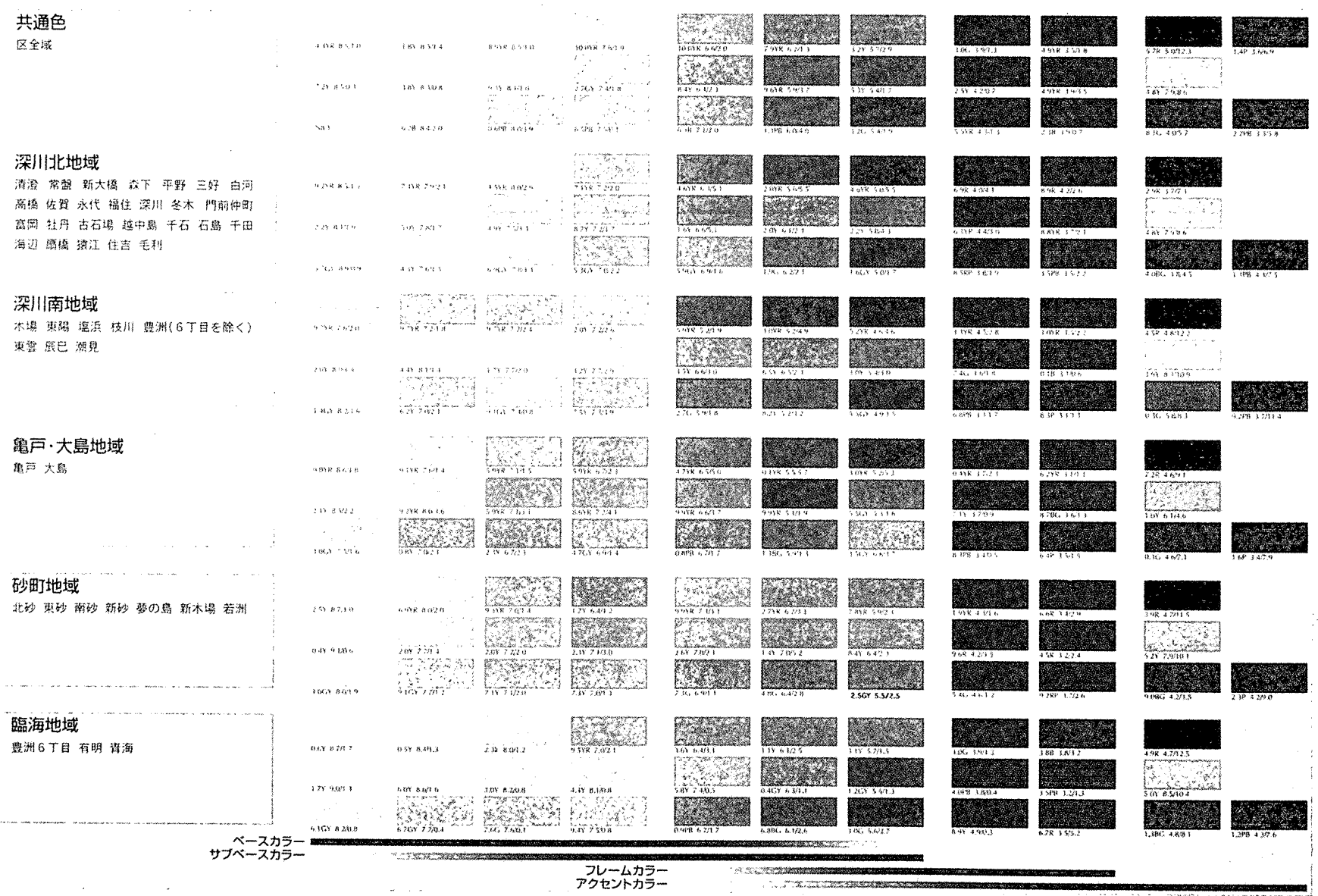

図12 江東区の䍗観色彩ガイド 
いる部分から、高明度・低彩度色をベースカラーに、中高明度・低 彩度色をサブベースカラーに、また中明度・中低彩度色をフレーム カラーとして読み取り、その色相を把握する。なお、提案色の中に は色相の均衡をとるために風土色から補充したのもある。アクセン トカラーは、赤・黄・緑・青·紫の色相を基本とし、その地域の色 彩特性を表す風土色を一色だけ選び、それに調和する色を選択す る。

(1)深川北地域は、図4の色彩傾向からこの地域に多く見られる黄系 黄赤系とこの地域の特性である緑系・赤紫を基に選ぶ。即ち、黄 系・黄赤系・黄緑系をベースカラーにし、黄系・黄赤系・黄緑系と 緑系をサブベースカラーにし、赤みを含んだ黄赤系・赤系・赤紫系 をフレームカラーにし、富岡八幡祭りの神興の青緑色をアクセント カラーとする。

(2)深川南地域は、図5の色彩傾向からこの地域に多く見られる黄系 黄赤系とこの地域の特性である無彩色を基に選ぶ。即ち、黄系と黄 赤系をベースカラーにし、ねずみ系をサブベースカラーにし、この 地域の特性である紫みを含んだ青紫系・紫系と黄赤系をフレームカ ラーにし、サザンカの赤色をアクセントカラーとする。

(3)亀戸・大島地域は、図6の色彩傾向からこの地域に多く見られる黄 系・黄赤系とこの地域の特性である黄緑色等を基に選ぶ。即ち、黄 赤系・黄系・黄緑系をベースカラーにし、黄赤系・黄緑系と青緑・ 青紫をサブベースカラーにし、深い緑系・赤系・紫系をフレームカ ラーにし、亀戸天神の鳥居の赤色をアクセントカラーとする。

(4)砂町地域は、図7の色彩傾向からこの地域に多く見られる黄系・黄 赤系・青紫系を基に選ぶ。即ち、黄赤系・黄系・黄緑系をべースカ ラーにし、黄赤系・黄系をサブベースカラーにし、黄赤系・赤系を フレームカラーにし、菜の花の黄色をアクセントカラーとする。 (5)臨海地域は、図8の色彩傾向からこの地域に多く見られる黄系・青 紫系を基に選ぶ。即ち、黄系をベースカラーにし、黄系・青紫をサ ブベースカラーにし、赤系・青系をフレームカラーにし、海の色の 青紫系をアクセントカラーとする。

\section{6. まとめ}

本研究は、東京都江東区を対象に、風土色と既存建築物の外壁色 の現況調査を行い、それに基ついて都市の色彩計画の提案を行った ものであり、その要旨は次ぎのとりである。

(1)地域固有の色を表す風土色については、気候、地形や地質等風土 の基本的な条件と直接関係する「自然環境に関わる色」と、その地 域における人々の生活の積み重ねが色になった「歴史・文化に関わ る色」という $2 つ の$ 視点を設けて、調查を行った。

(2)江東区の風土色としては、自然環境として土壤、植生、花、空と 水を調へ、歴史・文化環境として歴史的建築物、浮世絵、祭り、伝 統工芸品、のれん、地名等を調べた。これらは地域の風土条件が生 み出してきた最も調和のとれた色であり、それぞれの景観の中での 位置づけが読み取れる。即ち、ベースになる土䁃、空などの色、ア クセントになる花、祭り、工芸品等の色が把握できた。

(3)江東区の風土色における全体的な傾向は色相が多様であり、赤黄
（YR）系が中心になっている。深川北地域と亀戸・大島地域は、明 度が低く彩度が高く比較的深い色合いを示し、砂町地域は明度が高 く彩度が低く比較的柔らかい色合いを示している。深川北地域と深 川南地域は、全体的に黄赤系と青紫系が多い。亀戸 ·大島地域と砂 町地域は、全体的に黄赤系が多く、青紫系が少ない。

(4)既存建築物によって現況色彩を分析すると、集中的に分布してい るのは明度6から7.5、彩度2から3のYR系とY系である。この中に は、外壁色としては不適合な色である高明度色や高彩度色、中明 度・高彩度の濃い色、白に近い無彩色が多く使われている。特に、 青系の分布がばらついており、まちの色彩景観に混沌を与える大き な要因になっている。即ち、現在ベースとして使われている色は、 この地の風土が育んできている木、花、空、土壤の色よりあざやか な色(彩度が高い色)である。都市の中ではアクセントとして用いる べき色をべースとして用いたために、不調和をきたしている。 (5)提案の選定は、既存建築物の色彩分布傾向で多く見られる色相を 選び、それに当てはまる色調の色を風土色から選ぶ。 6以上の調査に基づき江東区の景観色彩ガイドをベースカラー、サ ブベースカラー、フレームカラー、アクセントカラーに分け、図12 のように提案した。

\section{謝辞}

本研究を進めるにあたり、江東区役所の建築調整係のご協力を得 たことに厚く感謝し、調査集計にご協力を頂きました京都大学大学 院環境地球工学専攻の百々敦浩君、田中俊樹君に、記して感謝の意 を表します。

1)文献にによる。

2)文献2による。

3)文献3による。

4)マンセルの表色系は、色相(Hue)、明度(Value)、彩度(Chroma)の3限性を合わせて一つの他

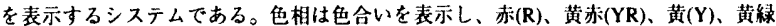

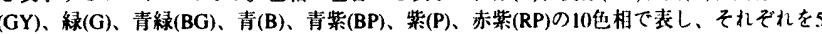
を中心とした1から10の数値で緗分する。明度は明るさを表示し、色が明るくなるにつ れて数値が大きくなる。無彩色（白一灰色一荲）はN 9のようにNをつけて表する。彩度 はあざやかさを表示し、色があざやかになるにつれて数优が大きくなる。撮大の数做は色 相によって異なる。

5)シルトは、土性の一つで、砂と粘土との中間の細かさの土を言う。

6)溒查期間は 5 月 $~ 6$ 月の間に測色を行った。

7)調查時の天気は晴れの日であり、調查期間は 5 月である。

8)江戸時代の庶民生活の風俗を生き生きと描写した浮世絵は、今日のような人エ材料や的料 がなかった当時の調利のとれた色彩文化を解䛨することができる。浮世絵からは、色とそ れがどこに使われていたかが分かる。

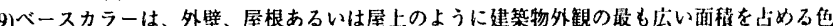
を指し、建物のイメージを決める色で一般的に低いトーンの色彩群を使う色と定䓔する。 10)サブベースカラーは、ベースカラーと組み合わせて用い、大面皘の壁面に適度な変化を あたえ、単調になるのを防ぐ色と定義する。

11)フレームカラーは、空染、手すり、壁面の一部などに線的に用いて、リスム感などを加 味したり、まちなみに龵序感や連続感を演出する色と定義する。

12)アクセントカラーは、小面皘に用いて個性を演出する色であり、ベースカラーやサフヘ 一スカラーに対して、コントラストを持ち配色全体を引き締める他と定義する。

13）「共通色」は、このガイドを実祭に地域に適用していく場合に、各地域の境界線にある 建物、例えば大通りを挟んでいる両側の建物や、江東区は３面が川に目まれているから川 沿いの連続景観を形成するために設定したものであり、江東区に其通な色として用いてよ いものである。

\section{考文嗝}

1) 和辻哲郎、風土、岩波文庫、1979

2）江束区、まちゔくり21〔江乘区都市整瘄方針〕、江東区、1994

3）江東区、汇東区都市景観ガイドライン、江東区、1996.

4) ヨハネス・イッテン、色彩論、美術出版社、1971.

5）佐藤邦夫、風土色と㖺好色、

6）朝日新聞社、色の博物誌、朝日新聞社、1986.

7) 朝日新聞社、色の彩時記、朝日新聞社、1986。

8)Mari OZAKI、GyungIn KIM、Masami KOBAYASHI (1997) 、Urban Color Design Based On

Cultural Climate-Case Study Of Koto Ward,Tokyo. The 8th Congress of International color Association, 1997.5 .

9)GyungIn KIM、Mari OZAKI、Masami KOBAYASHI（1997）、PRICIPLES OF KOREAN

COLORS. The 8th Congress of International color Association、1997.5.

10)江東区、「江東区景観色彩カイド」、東京都江東区、1997. 